\title{
КОМП’ЮТЕРНА ІМІТАЦЙНА МОДЕЛЬ ТЕХНОЛОГІЧНОГО ПРОЦЕСУ РЕАЛІЗАЦІЇ ГАЗОДИНАМІЧНОГО ТИСКУ НА РОЗПЛАВ ПРИ САМОГЕРМЕТИЗАЦІЇ ВИЛИВКА
}

Анотація. Стаття присвячена розробці комп'ютерної імітаційної моделі технологічного процесу реалізації газодинамічного тиску на розплав при самогерметизації виливка. Oписаний процес розроблення імітаційної моделі технологічного процесу на прикладі сталевого злитка. Значну увагу приділено етапу оцінки параметрів здійснення технології, який включає математичне моделювання процесу затвердіння сталевого виливка, аналіз температурних полів для визначення часу герметизації та темпу подачі регульованого газового тиску під час затвердіння виливка. Інформаційна модель технологічного процесу газодинамічного впливу на розплав в ливарній формі для сталевого злитка представлена у вигляді таблиці, що містить опис порядку проведення даного технологічного процесу, зміст етапів та їхню тривалість. Описано процедуру реалізації розробленої імітаційної моделі у вигляді комп'ютерної моделі - ігрового екшен додатку «Virtual Foundry». Представлений універсальний ігровий pipeline, який було реалізовано засобами графічного 3D моделювання з врахуванням сценарію взаємодії гравця з ігровим оточенням. Представлений інтерфейс графічного симулятора «Virtual Foundry», ігрові сцена та кадри 2D анімації. Відзначено наукову новизну розробленої інформаційної моделі технологічного процесу газодинамічного впливу на розплав в ливарній формі, реалізованої комп'ютерної імітаційної моделі у вигляді графічного симулятора «Virtual Foundry».

Ключові слова: Імітаційна модель, технологічний процес, графічний симулятор, unity engine, virtual foundry, газодинамічний вплив, якість навчання.

Вступ. В теперішній час розроблення об’єктів нової техніки й нових технологій потребує ефективного використання методів обчислювальної математики для вирішення проблем дослідження та адаптації в конкретних умовах застосування. Створення ефективних програмних засобів комп’ютерної реалізації розробок не можливе без модифікації й спеціалізації існуючих обчислювальних методів 3 метою підвищення їх ефективності, створення i

(C) Селівьорстова Т.В., 2021 


\section{«Системні технологіï» 5 (136) 2021 «System technologies»}

дослідження нових обчислювальних методів і алгоритмів, що враховують особливості реальних технічних та технологічних задач.

Технологічний процес газодинамічного впливу на розплав в ливарній формі включає в себе комплекс технічних, технологічних рішень та результати використання обчислювальних методів [1 - 5]. 3 іншого боку, невід’ємною частиною ефективного впровадження та експлуатації нової технології $\epsilon$ здійснення якісної підготовки відповідних інженерних та виробничих кадрів [6]. Наявний світовий досвід демонструє стрімке поширення використання комп’ютерних імітаційних моделей в навчальному процесі у вигляді ігрових інтерактивних додатків [7 - 10]. Застосування імітаційних моделей в навчальному процесі вкрай важливе, зокрема, і в умовах пандемії COVID-19 при дистанційному навчанні.

В роботі розглядається процедура розробки імітаційної моделі, що демонструє технологію газодинамічного впливу на розплав в ливарній формі.

Аналіз стану питання. Імітаційне моделювання застосовується у всіх сферах діяльності людини починаючи від моделей технічних, технологічних та організаційних систем. Реалізація імітаційної моделі у вигляді комп’ютерної моделі може бути використана для отримання нових знань про об'єкт та наближеної оцінки поведінки систем, занадто складних для аналітичного дослідження [11].

Особливістю технологічного процесу газодинамічного впливу на розплав в ливарній формі є його інженерна складність, що призводить до неможливості аналітичного опису і побудови формальних моделей. Як інструмент для аналізу цього технологічного процесу обрано імітаційне моделювання. В даному випадку імітаційне моделювання надає можливість відтворити технологічний процес в динаміці. Важливо відзначити, що імітуються елементарні явища, 3 яких складається процес, зі збереженням їх логічної структури і послідовності протікання в часі, що дозволяє за вихідними даними отримати відомості про стани процесу в певні моменти часу.

Метою роботи $\epsilon$ розробка комп’ютерної імітаційної моделі технологічного процесу газодинамічного впливу на розплав в ливарній формі, що наочно демонструє найбільш значущі особливості реалізації технології.

Основний матеріал. Відомо, що побудова комп'ютерної моделі базується на абстрагуванні від конкретної природи явищ або досліджуваного об'єктаоригіналу і складається 3 двох етапів [11]. Перший етап потребує створення інформаційної моделі у вигляді вербального опису, графіків, діаграм. Другий 
«Системні технології» 5 (136) 2021 «System technologies»

етап полягає в реалізації імітаційної моделі на базі інформаційної моделі шляхом застосування відповідних комп’ютерних технологій.

В основу інформаційної моделі технологічного процесу газодинамічного впливу на розплав в ливарній формі були покладені результати низки теоретичних [12, 13] та експериментальних досліджень [14, 15].

Розглянемо етапи технологічного процесу застосування газодинамічного тиску (таблиця 1) на прикладі сталевого злитка номенклатури ВАТ «ІНТЕРПАЙП НТЗ» (рисунок 1).

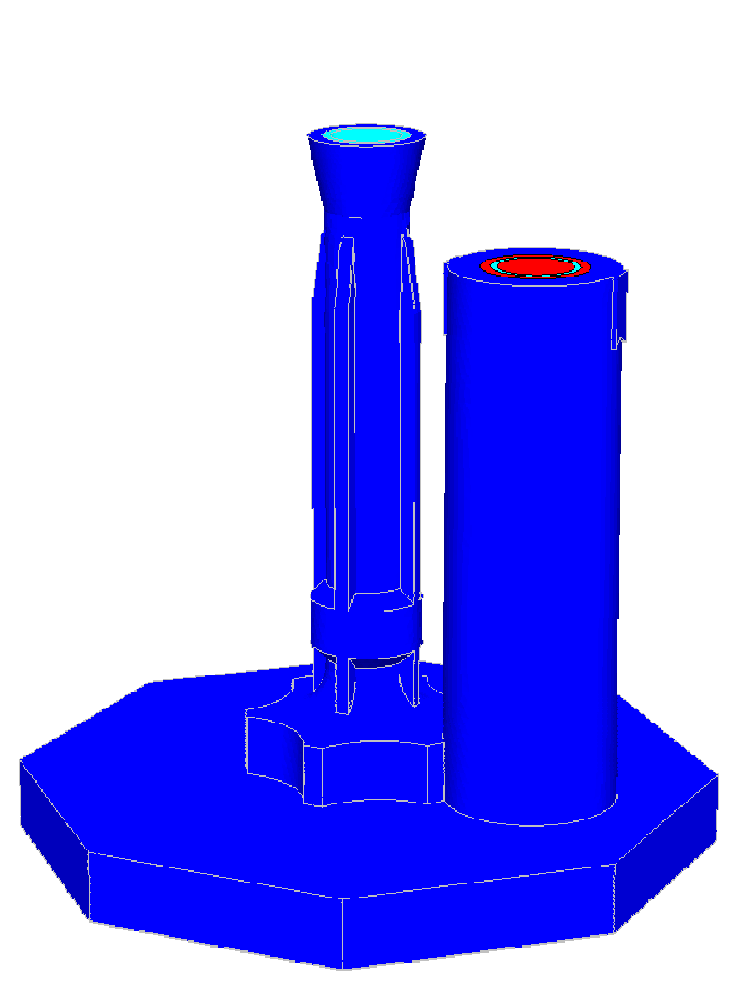

a

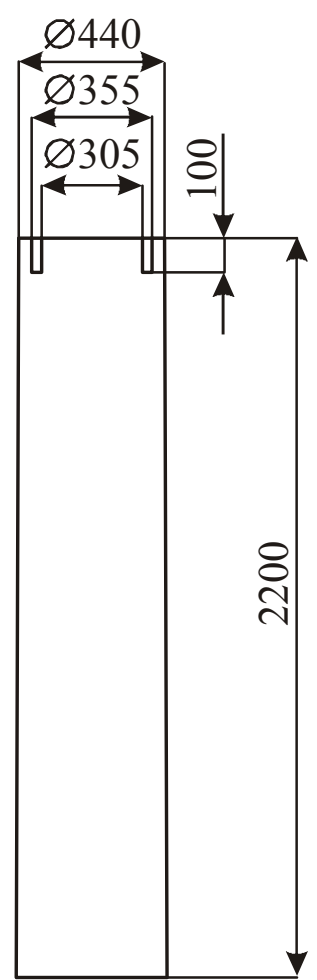

б

Рисунок 1 - Загальний вигляд ливарної форми (а) і схема розміщення корпусного холодильника в злитку з надливною вставкою (б)

Слід зазначити, що, зважаючи на різноманітність варіантів реалізації процесу ГДВ, яка пов’язана 3 можливістю використання для різних способів лиття, відповідно - різних умов затвердіння, варіантів виготовлення форм, конфігурації та маси виливків, видів сплавів та ін., тривалість окремих етапів може значно відрізнятися. Окрім того, перелік етапів може бути розширений при необхідності більш детального ознайомлення з окремими складовими процесу або планування конкретних технологічних операцій з точки зору забезпечення необхідною ресурсною базою. 
Інформаційна модель технологічного процесу газодинамічного впливу на розплав в ливарній формі сталевого злитка

\begin{tabular}{|c|c|c|c|}
\hline $\begin{array}{l}\text { Номер } \\
\text { етапу }\end{array}$ & Назва етапу & $\begin{array}{l}\text { Орієнтовна } \\
\text { тривалість } \\
\text { етапу }\end{array}$ & Опис етапу \\
\hline 1 & $\begin{array}{l}\text { Оцінка параметрів } \\
\text { здійснення технології }\end{array}$ & 20 - 40 год. & $\begin{array}{l}\text { Визначення часу, що необхідний для герме- } \\
\text { тизації виливка в ливарній формі, часу пов- } \\
\text { ного затвердіння виливка, розрахунок тер- } \\
\text { мочасових та динамічних режимів створення } \\
\text { тиску в системі виливок-пристрій для вве- } \\
\text { дення газу. }\end{array}$ \\
\hline 2 & Заливка розплаву & $7-10$ хв. & $\begin{array}{l}\text { Ківш з розплавом переміщується до центро- } \\
\text { вої (стояка), проводиться заливка розплаву } \\
\text { через сифонну ливникову систему. }\end{array}$ \\
\hline 3 & $\begin{array}{l}\text { Введення } \quad \text { пристрою } \\
\text { для подачі газу }\end{array}$ & До 5 хв & $\begin{array}{l}\text { Пристрій для подачі газу переміщується до } \\
\text { злитка за допомогою крану, занурюється в } \\
\text { надливну частину злитка. Приєднується до } \\
\text { газопроводу. }\end{array}$ \\
\hline 4 & Герметизація виливка & $100-150 c$ & $\begin{array}{l}\text { Утворення затверділого шару металу необ- } \\
\text { хідної міцності товщиною не менше } 10 \text { мм } \\
\text { на поверхні виливка. }\end{array}$ \\
\hline 5 & $\begin{array}{l}\text { Подача регульованого } \\
\text { газового тиску під час } \\
\text { затвердіння виливка }\end{array}$ & $65-70 \times \mathrm{x}$ & $\begin{array}{l}\text { За допомогою системи трубопроводів облад- } \\
\text { наної регулятором режиму подачі тиску газу } \\
\text { від зовнішнього джерела у вигляді балону } \\
\text { або компресорної установки. По закінченню } \\
\text { процесу припинення подачі газу та вирівню- } \\
\text { вання тиску в системі з атмосферним. }\end{array}$ \\
\hline 6 & $\begin{array}{l}\text { Видалення газопрово- } \\
\text { ду }\end{array}$ & $2-3 \mathrm{xв}$ & $\begin{array}{l}\text { Від’єднання гнучкого газопроводу від газо- } \\
\text { постачального патрубку корпусного холоди- } \\
\text { льника пристрою для введення газу. }\end{array}$ \\
\hline
\end{tabular}

Етап оцінки параметрів здійснення технології передбачає визначення принципової можливості реалізації технології гдВ на підставі, в тому числі, результатів комп'ютерного моделювання процесу затвердіння виливка. В даному випадку, комп'ютерне моделювання передбачає розв'язання теплової задачі та отримання температурних полів виливка з метою встановлення розташування теплових вузлів та оцінки якості їхнього живлення. Процедура моделювання може бути проведена з використанням спеціалізованого програмного забезпечення, як то MagmaSoft, ProCAST, SolidCast, CastCAE, NovaCast AB, 


\section{«Системні технології» 5 (136) 2021 «System technologies»}

WinCast, CSS (Casting Simulation Software) PoligonSoft, LVMFlow та інших [16]. Тривалість етапу оцінки параметрів здійснення технології істотно залежить від кваліфікації спеціаліста та його рівня володіння обраним програмним забезпеченням. В даному випадку креслення виливка і ливарної форми були виконані в середовищі твердотільного моделювання SolidWorks, моделювання процесу твердіння виливка виконані в PoligonSoft. В свою чергу, процедура моделювання в PoligonSoft складається з етапів:

- створення геометрії об’єкту моделювання (SolidWorks),

- розбиття 3D моделі на певну кількість кінцевих елементів (спеціалізоване програмне забезпечення Altair HyperMesh),

- імпорт підготовленого набору кінцевих елементів в PoligonSoft,

- вибір та задання теплофізичних властивостей матеріалу злитка (модуль «Сплав. Теплові властивості сплаву» PoligonSoft),

- вибір та задання теплофізичних властивостей матеріалів ливарної форми, надливної вставки (модуль «Сплав. Властивості матеріалів форми» PoligonSoft),

- визначення та задання граничних умов теплообміну на поверхні виливка, ливарної форми та між ними (модуль «Сплав. Параметри теплопередачi» PoligonSoft),

- визначення та задання початкових температур матеріалів злитка i форми (модуль «Сплав. Температура» PoligonSoft),

- визначення та задання усадкових властивостей сплаву (модуль «Сплав. Усадкові властивості сплаву» PoligonSoft),

- отримання температурних полів виливка в різні проміжки часу (модуль «Эйлер-3D» PoligonSoft),

- аналіз температурних полів з оцінкою кінетики затвердіння (засоби PoligonSoft).

В розглянутому випадку результати моделювання, наведені на рисунку 2, свідчать про те, що процес герметизації системи виливок-пристрій для подачі газу наступає через 100 секунд після завершення заливки. 
«Системні технології» 5 (136) 2021 «System technologies»

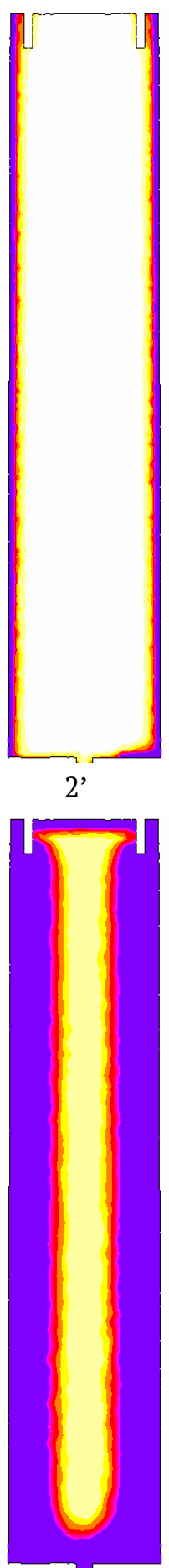

$42^{\prime}$

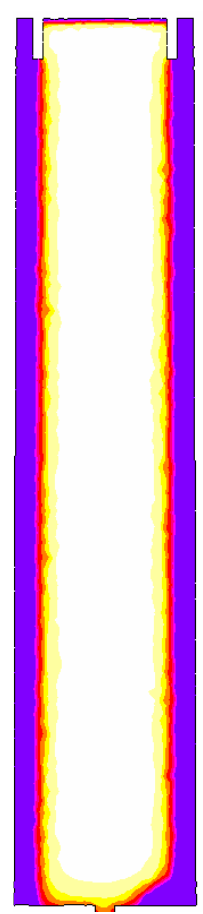

12

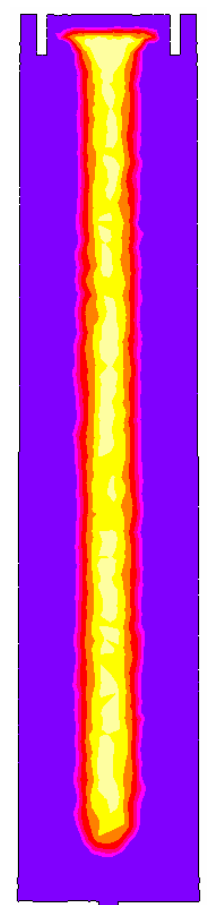

52

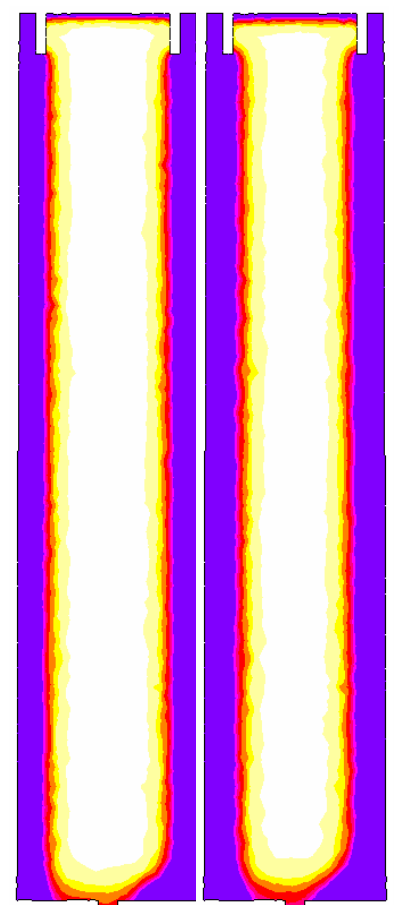

$17^{\prime}$

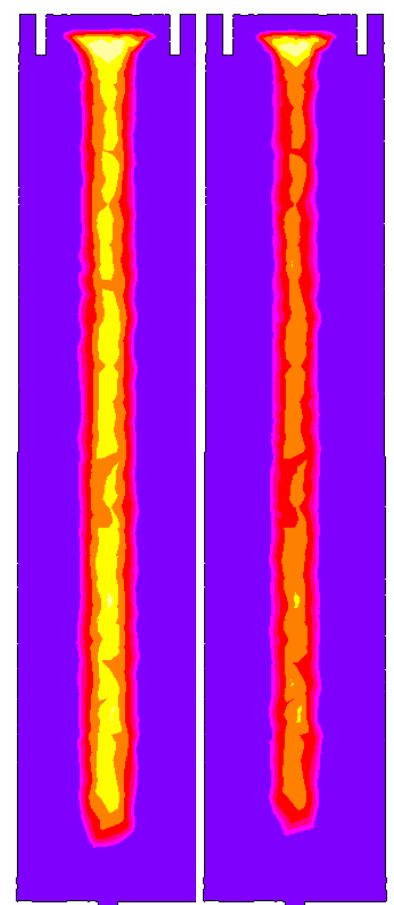

$57^{\prime}$

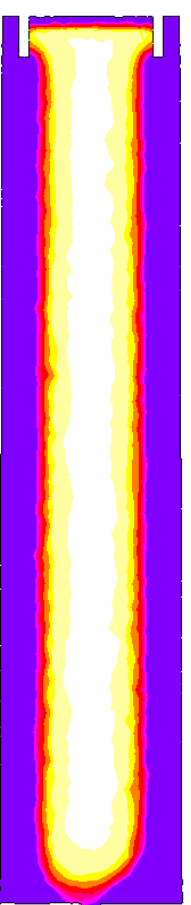

27

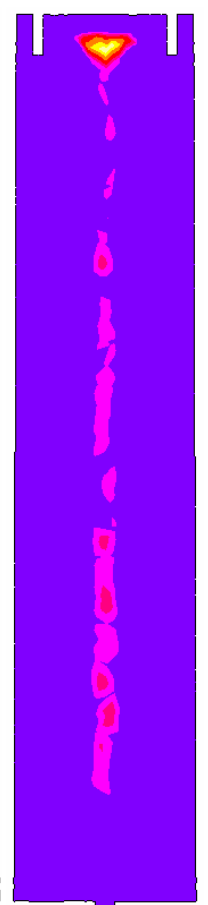

72

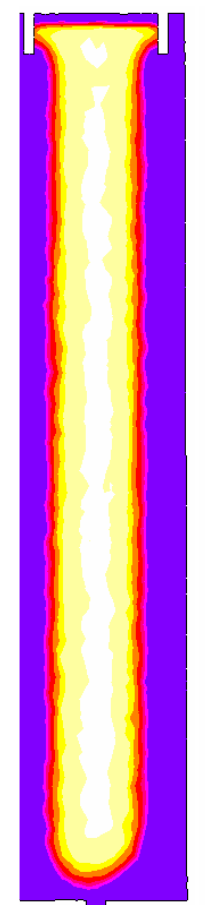

32

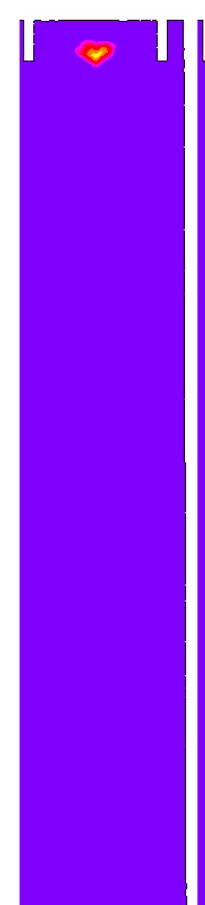

82

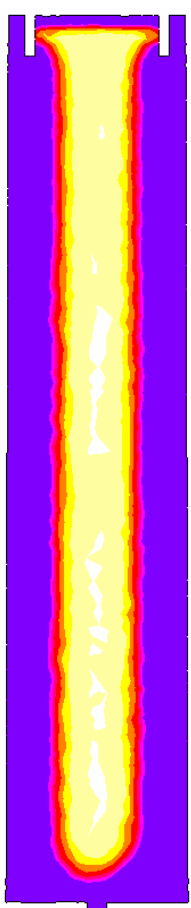

37

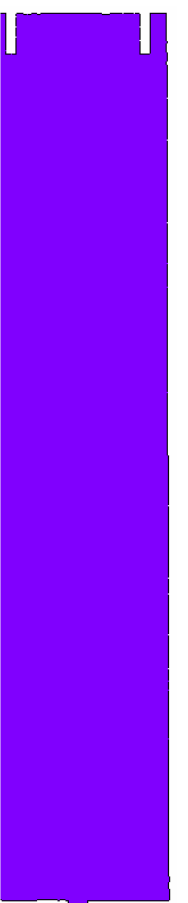

100

Рисунок 2 - Динаміка затвердіння злитка під дією сил гравітації і атмосферного тиску

Комп’ютерна імітаційна модель технологічного процесу реалізації газодинамічного тиску на розплав будується на базі інформаційної моделі (таблиця 1, рисунок 1) і представляє собою графічний інтерактивний ігровий додаток. Процедура розробки ігрових додатків досить складна і передбачає послідовне виконання етапів універсального ігрового pipeline (рисунок 3) [17]. 
«Системні технологіï» 5 (136) 2021 «System technologies»

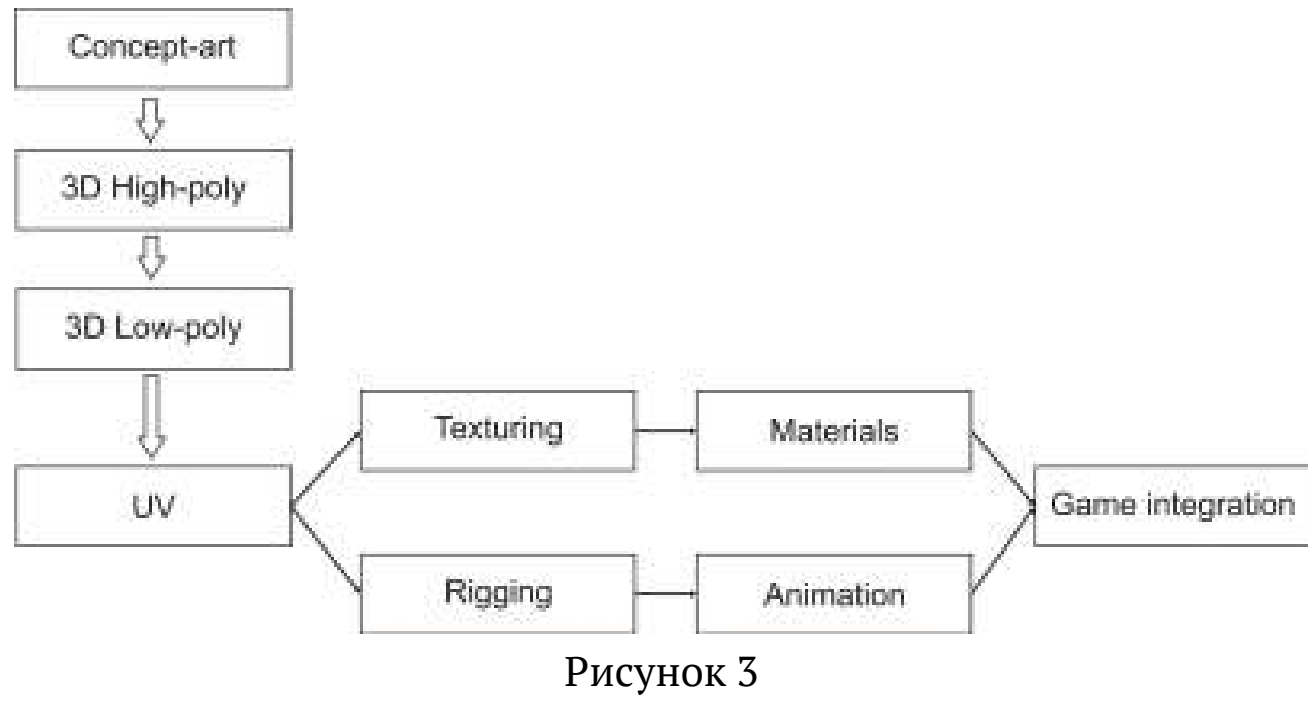

Відносно 3D графіки pipeline - це ланцюжок процесів перетворення сценарію в 2D, 3D картинку або в послідовність картинок - відео. Реалізація pipeline потребує послідовного застосування набору програмного забезпечення, що включає:

- Autodesk 3ds Max - 3D моделювання;

- Marmoset Toolbag 3 - запікання карт;

- Substance Painter - накладання текстур;

- Adobe Photoshop - додаткова графіка;

- Unity Engine - збірка додатку в програмному рушії.

В результаті реалізації pipeline сумісно з розробленим сценарієм взаємодії ігрового оточення з гравцем $[18,19]$ та інформаційною моделлю технології ГДВ було розроблено додаток у вигляді рольової екшен гри «Virtual Foundry» (рисунок 4).

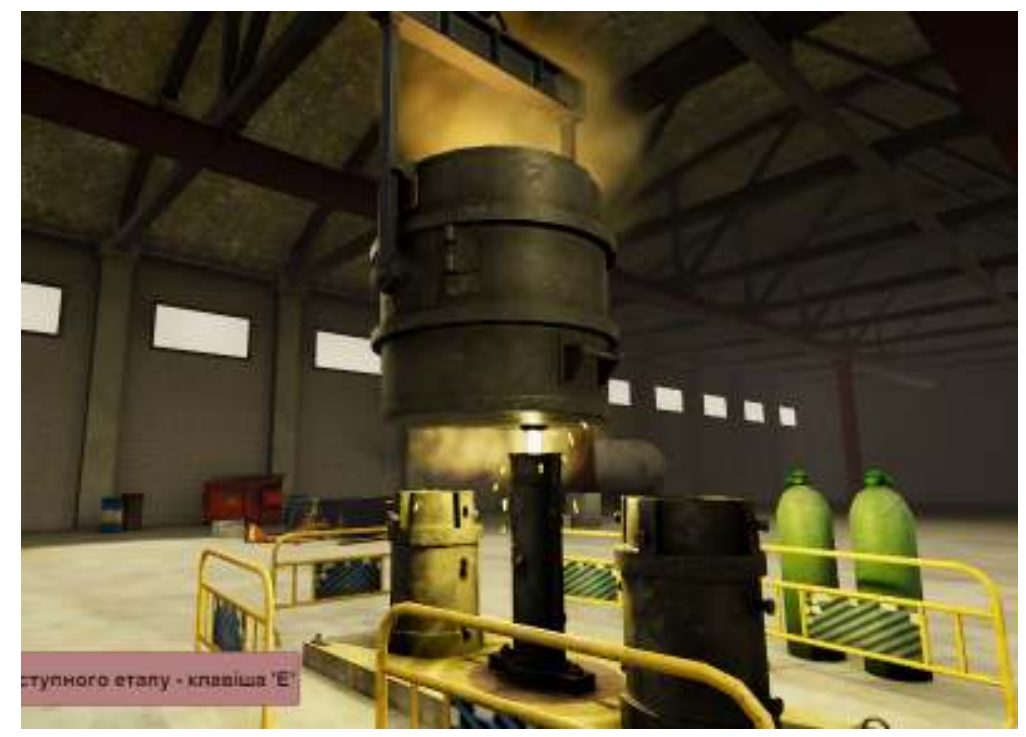

Рисунок 4 - Гра «Virtual Foundry», заливка розплаву в ливарну форму 


\section{«Системні технологіï» 5 (136) 2021 «System technologies»}

Гра «Virtual Foundry» представляє собою графічний симулятор, дії в якому відбуваються в ливарному цеху. Гравець виконує роль технолога або майстра ливарного цеху, має можливість переміщення по цеху, управляння технологічним процесом згідно розробленої інформаційної моделі. Крім того, реалізована можливість ознайомлення 3 динамікою процесу твердіння та утворення усадкових дефектів на перерізі виливку у вигляді 2D анімації (рисунок 5).

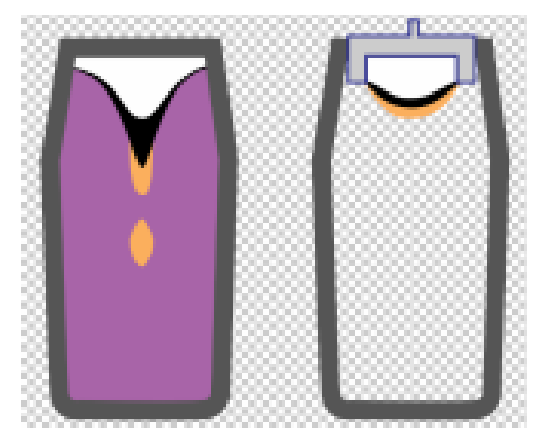

Рисунок 5 - Кадр 2D-анімації

Інтерфейс гри налаштований в Unity Engine (рисунок 6) і містить опис логічної структури гри «Virtual Foundry».

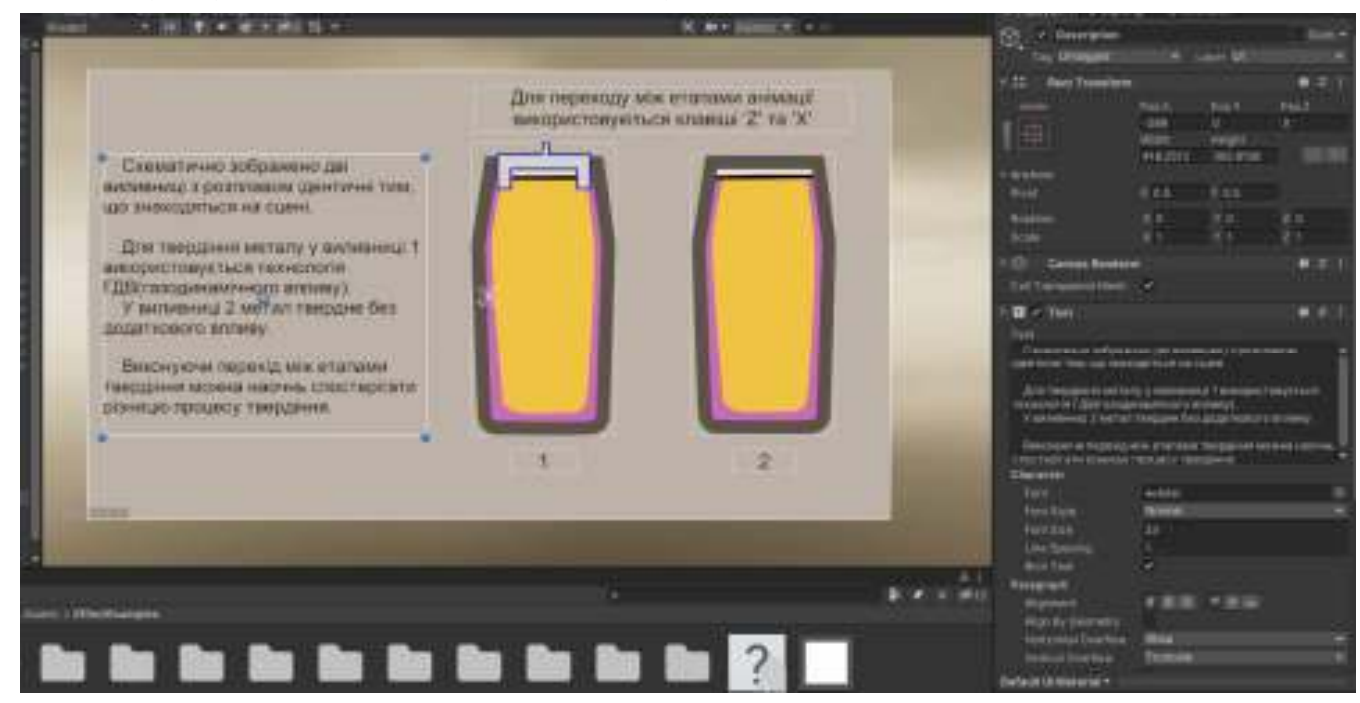

Рисунок 6 - Створення інтерфейсу користувача гри «Virtual Foundry» в Unity Engine

Висновки. В ході виконання роботи, що присвячена розробці комп’ютерної імітаційної моделі технологічного процесу газодинамічного впливу на розплав в ливарній формі, отримані наступні нові наукові результати:

1) вперше побудовано інформаційну модель технологічного процесу газодинамічного впливу на розплав в ливарній формі сталевого злитка; 


\section{«Системні технології» 5 (136) 2021 «System technologies»}

2) вперше реалізовано комп’ютерну імітаційну модель технологічного процесу газодинамічного впливу на розплав в ливарній формі у вигляді графічного симулятора «Virtual Foundry».

\section{ЛІТЕРАТУРА / ЛИТЕРАТУРА}

1. Селівьорстов В.Ю., Селівьорстова Т.В. Перспективи використання комплексних технологій газодинамічного впливу на розплав в ливарній формі // Системні технології. Регіональний міжвузівський збірник наукових праць. - Випуск 5 (130). - Дніпро, 2020. - С.122 - 143. МНБ: Index Copernicus, Ulrichsweb Global Serials Directory. ISSN 1562-9945 (Print), ISSN 2707-7977 (Online). https://doi.org/10.34185/1562-9945-5-130-2020-14

2. Пат. 28859 Україна, МПК (2006) B22D 18/00. Пристрій для отримання виливків / Селівьорстов В.Ю., Хричиков В.Є., Доценко Ю.В. - № 200708969; заявл.03.08.2007; опубл. 25.12.2007, Бюл.№21.

3. Пат. 37838 Україна, МПК (2006) B22D 18/00. Спосіб отримання виливків / Cелівьорстов В.Ю., Хричиков В.Є., Доценко Ю.В. - № 200808859; заявл.07.07.2008; опубл. 10.12.2008, Бюл.№23.

4. Пат. 37837 Україна, МПК (2006) B22D 18/00. Пристрій для отримання виливків / Селівьорстов В.Ю., Хричиков В.Є., Доценко Ю.В. - № 200808858; заявл. 07.07.2008; опубл. 10.12.2008, Бюл.№23.

5. Селівьорстов В.Ю. Особливості розрахунку газодинамічного впливу на метал, що твердіє в кокілі // Теорія і практика металургії. - 2009. - № 1-2. - С. 41 - 45.

6. Говоров А.И. Оценка актуальности разработки методов использования средств геймификации и игровых технологий в системах управления обучением / А. И. Говоров, М. М. Говорова, Ю. О. Валитова. // Компьютерные инструменты в образовании. - 2018. - №2. - С. 39-54. https://doi.org/10.32603/2071-2340-2018-2-39-54

7. Soboleva, E. V., Sokolova, A. N., Isupova, N. I., \& Suvorova, T. N. (2017). Use of training programs based on gaming platforms for improving the effectiveness of education. Novosibirsk State Pedagogical University Bulletin, 7(4), 7-25. doi:10.15293/2226-3365.1704.01

8. Zulkefli, N. A. M., Hashim, H., \& Syahrin, S. (2020). Evaluating e-learning google classroom tools for computer science subjects during covid-19 pandemic. International Journal of Advanced Trends in Computer Science and Engineering, 9(4), 6251-6258. doi:10.30534/ijatcse/2020/304942020

9. Surendeleg, G., Murwa, V., Yun, H. -., \& Kim, Y. S. (2014). The role of gamification in education - a literature review. Contemporary Engineering Sciences, 7(29-32), 1609-1616. doi:10.12988/ces.2014.411217

10. Wan Ishak, W. H., \& Yamin, F. M. (2020). Student acceptance on game to support teaching and learning. International Journal of Advanced Trends in Computer Science and Engineering, 9(3), 2517-2521. doi:10.30534/ijatcse/2020/05932020 


\section{«Системні технології» 5 (136) 2021 «System technologies»}

11. Строгалев В. П., Толкачева И. О. Имитационное моделирование. - МГТУ им. Баумана, 2008. - С. 697 - 737. - ISBN 978-5-7038-3021-5.

12. Селиверстов В.Ю. Технология газодинамического воздействия на расплав в литейной форме - один из перспективных способов повышения качества металла отливок // Сучасні проблеми металургії. Наукові праці. 2007. - Том 10. С. $25-35$.

13. Селиверстов В.Ю. Особенности процесса герметизации отливки в форме ЛВМ для осуществления газодинамического воздействия /В.Ю. Селиверстов, П.Д. Кущ //Теория и практика металлургии. - 2010. - № 5 - 6. - С. 95 - 98.

14. Селиверстов В.Ю., Михайловская Т.В., Доценко Ю.В., Мушенков Ю.А. Влияние газодинамического воздействия на распределение сульфидных включений в цилиндрической отливке из углеродистой стали, затвердевающей в кокиле // Металлургическая и горнорудная промышленность. - 2009. - №5. - С. 40 - 43.

15. Селівьорстов В.Ю., Хричиков В.Є., Куцова В.З., Носко О.А., Доценко Ю.В., Кущ П.Д. Особливості структуроутворення литої вуглецевої сталі при газодинамічному впливі // Теорія і практика металургії. - 2009. - № 5-6. - С. 80-85.

16. Токова О. В. Огляд методів та засобів комп’ютерного моделювання процесів ливарного виробництва / О. В. Токова. // Індуктивне моделювання складних систем. - 2017. - №9. - С. 204-213.

17. Marco. Game Development Pipeline: From Concept To Store [Електронний ресурс] / Marco - Режим доступу до ресурсу:

https://gamedevelopertips.com/game-development-pipeline/.

18. Чернов О.Д., Селівьорстова Т.В., Селівьорстов В.Ю. Особливості реалізації інтерактивного додатку для вивчення технології газодинамічного впливу на розплав в ливарній формі // V Всеукраїнська науково-практична конференція 3 міжнародною участю «Сучасні інформаційні технології в освіті та науці» 12 листопада 2020 р. С. 139 - 143.

19. Селівьорстова Т.В., Селівьорстов В.Ю., Чернов О.Д. Особливості реалізації графічного інтерактивного ігрового додатку для ознайомлення 3 технологією газодинамічного впливу на розплав в ливарній формі //Системні технології. Дніпро, 2021. - Вип. 1 (131). - С. 3 - 21.

\section{REFERENCES}

1. Selivorstov VY, Selivorstova TV Prospects for the use of complex technologies of gas-dynamic influence on the melt in the mold // System technologies. Regional interuniversity collection of scientific works. - Issue 5 (130). - Dnipro, 2020. - P.122 143. MNB: Index Copernicus, Ulrichsweb Global Serials Directory. ISSN 1562-9945 (Print), ISSN 2707-7977 (Online).

https://doi.org/10.34185/1562-9945-5-130-2020-14

2. Pat. 28859 Ukraine, IPC (2006) B22D 18/00. Device for obtaining castings / Seliverstov VY, Khrychikov VE, Dotsenko YV - № 200708969; application 03.08.2007; publ. 25.12.2007, Bull.№21. 


\section{«Системні технології» 5 (136) 2021 «System technologies»}

3. Pat. 37838 Ukraine, IPC (2006) B22D 18/00. The method of obtaining castings / Seliverstov VY, Khrychikov VE, Dotsenko YV - № 200808859; application 07.07.2008; publ. 10.12.2008, Bull.№23.

4. Pat. 37837 Ukraine, IPC (2006) B22D 18/00. Device for obtaining castings / Seliverstov VY, Khrychikov VE, Dotsenko YV - № 200808858; declared 07.07.2008; publ. 10.12.2008, Bull.№23.

5. Seliverstov V.Yu. Features of calculation of gas-dynamic influence on the metal hardening in a mold // Theory and practice of metallurgy. - 2009. -№ 1-2.- P. 41 - 45. 6. Govorov A.I. Assessment of the relevance of developing methods for using gamification tools and game technologies in learning management systems / A.I. Govorov, M.M. Govorova, Yu.O. Valitova. // Computer tools in education. - 2018. No. 2. - S. 39-54. https://doi.org/10.32603/2071-2340-2018-2-39-54

7. Soboleva, E. V., Sokolova, A. N., Isupova, N. I., \& Suvorova, T. N. (2017). Use of training programs based on gaming platforms for improving the effectiveness of education. Novosibirsk State Pedagogical University Bulletin, 7(4), 7-25. doi:10.15293/2226-3365.1704.01

8. Zulkefli, N. A. M., Hashim, H., \& Syahrin, S. (2020). Evaluating e-learning google classroom tools for computer science subjects during covid-19 pandemic. International Journal of Advanced Trends in Computer Science and Engineering, 9(4), 6251-6258. doi:10.30534/ijatcse/2020/304942020

9. Surendeleg, G., Murwa, V., Yun, H. -., \& Kim, Y. S. (2014). The role of gamification in education - a literature review. Contemporary Engineering Sciences, 7(29-32), 1609-1616. doi:10.12988/ces.2014.411217

10. Wan Ishak, W. H., \& Yamin, F. M. (2020). Student acceptance on game to support teaching and learning. International Journal of Advanced Trends in Computer Science and Engineering, 9(3), 2517-2521. doi:10.30534/ijatcse/2020/05932020

11. Strogalev V., Tolkacheva I. Simulation modeling. - MSTU im. Bauman, 2008 .-S. 697 - 737.

12. Seliverstov V.Yu. The technology of gas-dynamic action on the melt in a casting mold is one of the most promising ways to improve the quality of the metal of castings // Modern problems of metallurgy. Scientific works. 2007. - Volume 10. P. $25-35$.

13. Seliverstov V.Yu. Features of the process of sealing a casting in the form of a LVM for the implementation of gas-dynamic action / V.Yu. Seliverstov, P.D. Kushch // Theory and practice of metallurgy. - 2010. - No. 5 - 6. - P. 95 - 98.

14. Seliverstov V.Yu., Mikhailovskaya T.V., Dotsenko Yu.V., Mushenkov Yu.A. Influence of gas-dynamic impact on the distribution of sulfide inclusions in a cylindrical casting made of carbon steel, solidified in a chill mold // Metallurgical and mining industry. - 2009. - No. 5. - P. 40 - 43. 


\section{«Системні технології» 5 (136) 2021 «System technologies»}

15. Seliverstov V., Khrychikov V., Kutsova V., Nosko O., Dotsenko Y., Kushch P. Peculiarities of structure formation of cast carbon steel under gas-dynamic influence // Theory and practice of metallurgy. - 2009. - № 5-6. - P. 80-85.

16. Tokova O. Review of methods and means of computer modeling of foundry production processes / OV Tokova. // Inductive modeling of complex systems. - 2017. №9. - P. 204-213.

17. Marco. Game Development Pipeline: From Concept To Store [Electronic resource] / Marco - Режим доступу до ресурсу

https://gamedevelopertips.com/game-development-pipeline/.

18. Chernov O., Seliverstova T., Seliverstov V. Features of implementation of an interactive application for studying the technology of gas-dynamic influence on the melt in the mold // V All-Ukrainian scientific-practical conference with international participation "Modern information technologies in education and science" November 12, 2020 P. 139 - 143.

19. Selivorstova T., Selivorstov V., Chernov O. Peculiarities of realization of graphic interactive game application for acquaintance with technology of gas-dynamic influence on melt in foundry form // System technologies. - Dnipro, 2021. - Issue. 1 (131). - P. 3 - 21.

Received 15.05.2021. Accepted 17.05.2021.

\section{Компьютерная имитационная модель технологического процесса реализации газо-} динамического давления на расплав при самогерметизации отливки

Статья посвящена разработке компьютерной имитационной модели технологического процесса реализации газодинамического давления на расплав при самогерметизации отливки. Описан процесс разработки имитационной модели данного технологического процесса на примере стального слитка. Значительное внимание уделено этапу оценки параметров осуществления технологии, который включает математическое моделирование процесса затвердевания стального слитка, анализ температурных полей для определения времени герметизации и темпа подачи регулируемого газового давления во время затвердевания отливки. Информационная модель технологического процесса газодинамического воздействия на расплав в литейной форме для стального слитка представлена в виде таблицы, содержащей описание порядка проведения данного технологического процесса, содержание этапов и их продолжительность. Описана процедура реализации разработанной имитационной модели в виде компьютерной модели - игрового экшен приложения «Virtual Foundry». Представлен универсальный игровой pipeline, который был реализован средствами графического 3D моделирования с учетом сценария взаимодействия игрока с игровым окружением. Представлен интерфейс графического симулятора "Virtual Foundry», игровая сцена и кадры 2D анимации. Отмечены научная новизна разработанной информационной модели технологического процесса газодинамического воздействия на расплав в литейной форме, реализованной компьютерной имитационной модели в виде графического симулятора «Virtual Foundry». 


\section{«Системні технології» 5 (136) 2021 «System technologies»}

\section{Computer simulation model of the technological process of realizing gas-dynamic pressure on the melt during self-sealing of the casting}

The article is devoted to the development of a computer simulation model of the realizing gas-dynamic pressure technological process on the melt during self-sealing of a casting. The process of developing a simulation model of this technological process is described on the example of a steel ingot.

Considerable attention is paid to the stage of evaluating the parameters of the technology implementation, which includes mathematical modeling of the steel ingot solidification process, analysis of temperature fields to determine the sealing time and the rate of controlled gas pressure supply during the solidification of the casting.

The information model of the gas-dynamic action technological process on the melt in a casting mold for a steel ingot is presented in the form of a table containing a description of the procedure for carrying out this technological process, the content of the stages and their duration. This information model contains the following stages: assessment of technology implementation parameters, pouring melt, gas supply device introduction, casting sealing, supply of regulated gas pressure during the solidification of the casting, pipeline removal.

The procedure for the implementation of the developed simulation model in the form of a computer model - a game "Virtual Foundry" application is described. A universal game pipeline is presented, implemented by means of graphical 3D modeling, taking into account the scenario of the player's interaction with the game environment. The interface of the Virtual Foundry graphic simulator, the game scene and 2D animation frames are presented.

The scientific novelty of the technological process of gas-dynamic influence developed information model on the melt in a casting mold, implemented by a computer simulation model in the form of a graphic simulator "Virtual Foundry" is noted.

Селиверстова Татьяна Витальевна - к.т.н., доцент, доцент кафедры информационных технологий и систем, Национальная маталлургическая академия Украины, ORCID 0000-0002-2470-6986.

Селівьорстова Тетяна Віталіївна - к.т.н., доцент, доцент кафедри інформаційних технологій та систем, Національна металургійна академія України, ORCID 0000-0002-2470-6986.

Selivyorstova Tatjana - candidate of technical science, assistant professor, Department of information technology and systems, The National Metallurgical Academy of Ukraine, ORCID 0000-0002-2470-6986 